\title{
РЕДКИЕ МЕТАЛЛЫ В МИНЕРАЛАХ ОЛОВОНОСНЫХ МЕТАСОМАТИТОВ ВЕРХНЕУРМИЙСКОГО РУДНОГО УЗЛА (ДАЛЬНИЙ ВОСТОК РОССИИ)
}

\author{
В.И.АЛЕКСЕЕВ \\ Санкт-Петербургский горный университет, Санкт-Петербург, Россия
}

\begin{abstract}
Исследована редкометалльная минерализация оловоносных метасоматитов Верхнеурмийского рудного узла на Дальнем Востоке России. Изучен минеральный состав метасоматитов пяти стадий формирования цвиттер-турмалинитового оловоносного комплекса: биотит-серицитовой, мусковит-кварцевой, сидерофиллит-топазовой, кварц-турмалиновой и хлорит-серицитовой. Выделены минералы, содержащие редкие металлы, и оценены концентрации редких металлов.

Определена рудно-геохимическая специализация метасоматитов Верхнеурмийского рудного узла. Показано наличие в составе оловоносных метасоматитов района множества минералов редких металлов, имеющих стратегическое значение для развития минерально-сырьевой базы России: Nb, Ta, W, Y, REE (весь спектр от La до Lu), Be, Li, Zr, Hf, In, Sc, Se, Cd. Минералы-концентраторы редких металлов разделены на собственно редкометалльные и минералы (жильные и рудные) с изоморфными примесями редких металлов.

Изучена последовательность образования минералов-концентраторов редких металлов района и прослежена эволюция их видового состава. Минералы редких металлов образуются в течение всей истории формирования цвиттер-турмалинитовой формации - от предрудной стадии биотитовых фельдшпатолитов до пострудной стадии хлорититов, включая рудную стадию цвиттеров. Выявлено постадийное снижение интенсивности редкометалльного минералообразования и эволюция состава минерализации от литофильных редких металлов к халькофильным: (LREE, $\mathrm{Zr}, \mathrm{Hf}) \rightarrow(\mathrm{W}, \mathrm{Nb}, \mathrm{Ta}, \mathrm{Y}, \mathrm{HREE}, \mathrm{Sc}) \rightarrow(\mathrm{Sn}, \mathrm{In}, \mathrm{Cd}, \mathrm{Se})$.

Выявлены магматический, метасоматический и кристаллохимический факторы образования минераловконцентраторов редких металлов Верхнеурмийского рудного узла. Перспективы узла связаны с наличием литий-фтористых гранитов правоурмийского комплекса, контролирующих размещение вольфрамовооловорудных цвиттеров и турмалинитов с попутной редкометалльной минерализацией.

Ключевые слова: редкие металлы; литий-фтористые граниты; биотититы; грейзены; цвиттеры; турмалиниты; хлорититы; Верхнеурмийский рудный узел; Дальний Восток России
\end{abstract}

Как цитировать эту статью: Алексеев В.И. Редкие металлы в минералах оловоносных метасоматитов верхнеурмийского рудного узла (Дальний Восток России) // Записки Горного института. 2018. Т. 232. C. 335-340. DOI: 10.31897/PMI.2018.4.335

Введение. Понятие «редкие металлы» постоянно меняет свое содержание, в зависимости от развития геологоразведочных и перерабатывающих технологий и конъюнктуры сырьевого рынка. Неизменными критериями «редкого металла» со времен Д.И.Менделеева и В.И.Вернадского остаются низкий кларк и технологическая востребованность химического элемента [6, 16]. Россия имеет значительный ресурсный потенциал редких металлов, источниками которых служат, в частности, месторождения с редкометалльными гранитами. Промышленная минерализация таких месторождений (колумбит, пирохлор, циркон, фергусонит и др.) связана с фельдшпатолитами, сопровождающими щелочные граниты (Катугин, Забайкалье; Улуг-Танзек, Тува; Ермаковское, Бурятия и др.), тогда как цвиттеры, связанные с субщелочными Li-F-гранитами, несут вольфрамово-оловянную минерализацию (Тигриное, Приморье; Одинокое, Якутия; Иультин, Чукотка и др.) [15].

Одним из путей развития сырьевой базы редких металлов России является минералогогеохимическая переоценка ранее разведанных вольфрамово-оловорудных месторождений Дальнего Востока, связанных с Li-F-гранитами $[2,12]$. Необходимо выяснить, какие редкие элементы и в каких концентрациях заключены в тех или иных минералах этих месторождений, какие минералы являются промышленными носителями редких элементов. Это обеспечит получение критериев оценки вольфрамово-оловорудных месторождений на попутные редкие металлы. В одном из известных районов Приамурья - Верхнеурмийском медь-вольфрам-оловорудном узле, ранее выявлены некоторые минералы редких металлов цвиттер-турмалинитовой метасоматической формации и прослежена эволюция их видового состава $[4,5]$. В данной статье исследована редкометалльная минерализация метасоматитов пяти стадий формирования этого рудного узла: биотититов $\rightarrow$ мусковитовых грейзенов $\rightarrow$ цвиттеров $\rightarrow$ турмалинитов $\rightarrow$ хлорититов $[3,11]$. Цель 
работы - выявление в составе оловоносных метасоматитов минералов, содержащих редкие металлы, изучение эволюции редкометалльной минерализации и первичная оценка ее практического значения.

Методология и методы исследования. Научно-методической основой работы является системно-целевой подход к изучению гидротермально-метасоматических образований. Основополагающий принцип исследования - рациональное комплексирование методов изучения структурно-геологической, метасоматической, минералогической, геохимической и рудной зональности на основе крупномасштабного геологического картирования [13]. Минералогическое изучение метасоматитов включает оценку их состава и строения, выделение минералов-индикаторов горных пород, исследование конституции минералов и их роли в петро- и рудогенезе $[2,3,11]$.

Особое внимание уделено рудным и жильным минералам, содержащим редкие металлы. На участках минерализации, выявленных по данным геохимического картирования, производился отбор представительных проб метасоматитов, их петрографическое и геохимическое изучение в Центре коллективного пользования Санкт-Петербургского горного университета с помощью эмиссионного спектрального и рентгено-спектрального флуоресцентного анализа (ED-2000, XRF-1800), масс-спектрометрии с индуктивно-связанной плазмой (ICPE-9000). В пробах с повышенным содержанием редких металлов был проведен электронно-микроскопический поиск минералов-носителей (JSM-6460LV, JSM-7001F, JIB-4500, Сameca MS-46). Химический состав слюд, флюорита, вольфрамита, касситерита, сульфидов определен методами «мокрой химии», ICP-MS, AAS. Состав микроминералов исследован на электронно-зондовых микроанализаторах с волновыми и энергодисперсионными спектрометрами (CamScan MV2300, JSM-7001F, JXA-8230).

Оловоносные метасоматиты района. Верхнеурмийский рудный узел (ВУРУ) входит в состав Баджальского рудного района, расположенного в Хингано-Охотском вулканическом поясе $[9,10]$. Баджальский район расположен в эпицентре крупнейшего астеносферного купола, фиксируемого отрицательной аномалией силы тяжести и интенсивным тепловым потоком литосферы [2]. В строении ВУРУ выделяется мощная меловая толща кислых вулканитов, пронизанная
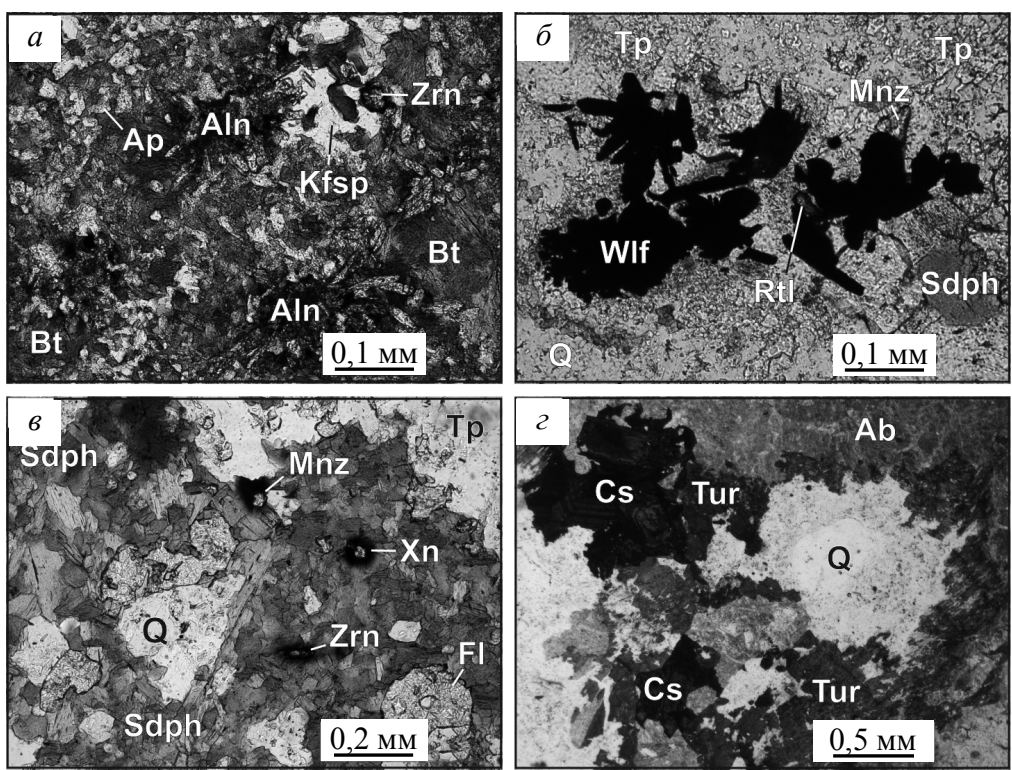

Минералы, содержащие редкие металлы, в оловоносных метасоматитах Верхнеурмийского рудного узла (микрофотографии шлифов без анализатора, Leica DM750P):

$a$ - калишпат-кварц-биотитовый метасоматит с алланитом-(Се), Нf-цирконом, $\mathrm{Ce}$-апатитом; $\sigma$ - сидерофиллит-кварц-топазовый цвиттер с $\mathrm{Nb}$-вольфрамитом, $\mathrm{Nb}-\mathrm{W}$-рутилом, монацитом-(Ce); в - топаз-кварц-сидерофиллитовый цвиттер с Y-флюоритом, монацитом-(Се), ксенотимом-(Y), Нf-цирконом; 2 - альбиткварц-турмалиновый метасоматит с In- $\mathrm{Nb}$-касситеритом. Минералы: $\mathrm{Ab}$ - альбит, $\mathrm{Aln}$ - алланит-(Ce), Ap - апатит-(CaF), Cs - касситерит, Fl- флюорит, Kfsp полевой шпат, $\mathrm{Mnz}$ - монацит-(Ce), Sdph - сидерофиллит, Tp - топаз, Tur турмалин, Q - кварц, Xn - ксенотим-(Y), Zrn - циркон субвулканическими и гипабиссальными гранитовыми интрузиями. Верхнеурмийский рудный узел занимает площадь Верхнеурмийского гранитового плутона и примыкающего к нему Урмийского игнимбритового вулканогена. В Верхнеурмийском массиве биотитовых гранитов выделены литий-фтористые граниты правоурмийского комплекca, под воздействием которых в восточной приконтактовой зоне массива происходило формирование рудоносных метасоматитов цвиттертурмалинитовой формации и образование крупного Правоурмийского вольфрамово-оловорудного месторождения $[1-3,10,11,14]$.

Наиболее ранними оловоносными образованиями района являются гидротермалиты биотитсерицитовой (первой) стадии, представленные биотит-полевошпатовыми и биотит-серицитовыми метасоматитами. Предрудные биотититы слагают крутопадающие зоны мощностью 0,1-2 м и протяженностью 2-200 м на 
рудопроявлениях Осьбаджальского (Вольфрам-Макит, Двойное), Правоурмийского (Правоурмийское, Дождливое, Аленушкино, Сульфидное), Вольфрамового (Лесное) и Сынчугинского (Высокое, Длинное) рудных полей. Биотитовые фельдшпатолиты сложены биотитом, мусковитом, альбитом, калиевым полевым шпатом; содержат в подчиненных количествах кварц, гранат, турмалин. Акцессорные и рудные минералы - пирротин, халькопирит, флюорит, апатит, рутил, шеелит. В составе биотититов выделены минералы, содержащие редкие металлы: алланит-(Се), циркон, монацит-(Се), ксенотим-(Y), апатит-(F), ильменит, торит, биотит (см. рисунок, $a$ ).

На биотитовые метасоматиты наложены грейзены мусковит-квариевой (второй) стадии, которыми сложены крутопадающие зоны мощностью 0,1-4,0 м (до 20 м) и протяженностью 200-1800 м на рудопроявлениях Грустное, Гранитное, Улун, Вольфрам-Макит (рудное поле Ось Баджала); Аленушкино, Южное, Геофизическое (Правоурмийское поле); Лесное (Вольфрамовое поле), Высокое, Ветвистое (Сынчугинское поле). Состав метасоматитов мусковит-кварцевый; пронизывающие их кварцевые жилы содержат мусковит, флюорит и сульфиды. Рудные минералы касситерит, вольфрамит, молибденит, висмутин и арсенопирит. Минералы, содержащие редкие металлы, в мусковитовых грейзенах представлены касситеритом, вольфрамитом, молибденитом и мусковитом.

Сидерофиллит-топазовая (третья) стадия включает образование многочисленных тел вольфрамово-оловорудных цвиттеров месторождения Правоурмийское и рудопроявлений Вольфрам-Макит, Двойное (Ось Баджала); Лесное (Вольфрамовое поле), Высокое (Сынчугинское поле) $[5,9,14]$. Цвиттеры слагают мощные (до 40 м) залежи и маломощные ( $n$ сантиметров) околожильные ореолы в штокверках топазовых и кварцевых прожилков. Метасоматиты сложены кварцем, сидерофиллитом, топазом, мусковитом, а их размещение контролируется Li-Fгранитами $[2,3]$. Состав акцессорной и рудной минерализации цвиттеров: флюорит, касситерит, вольфрамит, арсенопирит, леллингит, берилл, шеелит, самородный висмут, висмутин и др. Минералы оловорудных цвиттеров, содержащие редкие металлы: фергусонит-(Y), эвксенит-(Y), плюмбопирохлор, монацит-(Се), ксенотим-(Y), циркон, берилл, вольфрамит, касситерит, шеелит, сфалерит, самородный висмут, рутил, сидерофиллит, мусковит, флюорит (рисунок, $\sigma, 6)$.

Особенностью продуктов квари-турмалиновой (четвертой) стадии является преобладание существенно турмалиновых метасоматических жил мощностью до 40 см с околожильным окварцеванием и альбитизацией вмещающих пород. На грейзеновых проявлениях (Правоурмийское, Вольфрам-Макит, Гранитное, Лесное, Высокое) они приурочены к телам кварцтопазовых и мусковит-кварцевых оловорудных грейзенов. Существенна роль околожильных метасоматитов в крутопадающих зонах оловорудных турмалинитов мощностью 0,3-9 м и протяженностью 500-600 м рудопроявлений Двойное, Проскурникова, Орокот, Омот-Макит (поле Ось Баджала); Дождливое (Правоурмийское поле); Длинное, Восточное (Сынчугинское поле). Турмалиниты сложены агрегатом кварца, серицита, альбита с примесью турмалина, хлорита, флюорита; содержат вкрапленность и прожилки касситерита, халькопирита и борнита, реже встречаются станнин, станноидит, моусонит, виттихенит, сфалерит, пирротин, пирит, самородный висмут. Минералы турмалинитов, содержащие редкие металлы, - монацит-(Се), циркон, шеелит, рокезит, касситерит, вольфрамит, халькопирит, станноидит, борнит, самородный висмут, пирит, эпидот, флюорит (рисунок, г).

Метасоматиты хлорит-серицитовой (пятой) стадии развиты вдоль крутопадающих разломов и пологих взбросов, образуя зоны мощностью 0,1-83 м, протяженностью 500-1600 м на рудопроявлениях Хлоритовое, Ирунгда-Макит (поле Ось Баджала); Правый Омот, Сульфидное (Правоурмийское поле); Восточное (Сынчугинское поле). Породообразующие минералы пострудных хлорититов - хлорит, альбит, серицит, кварц; второстепенные минералы - эпидот, кальцит, турмалин, пренит, цеолиты. Акцессорные и рудные минералы - флюорит, пирит, сфалерит, галенит, касситерит, антимонит. Минералы хлорититов, содержащие редкие металлы, - сфалерит, галенит, флюорит, эпидот.

Редкие металлы в минералах оловоносных метасоматитов Верхнеурмийского рудного узла. В метасоматитах биотит-серицитовой стадии среди редкометалльных минералов наибольший интерес представляет алланит-(Се) (рисунок, a). Минерал содержит 4,76-17,52 $\mathrm{Ce}_{2} \mathrm{O}_{3}{ }^{*}$;

* Массовое содержание всех элементов и минералов указано в процентах. 
общее содержание легких $\mathrm{P} 3 Э$ ( $\mathrm{La}, \mathrm{Ce}, \mathrm{Nd}$ ) 6,78-26,52; $\mathrm{ThO}_{2}$ до 3,93; $\mathrm{SnO}_{2}$ до 0,93. На рудопроявлении Сульфидное встречен алланит, содержащий $\mathrm{Y}_{2} \mathrm{O}_{3}$ до 8,56. В биотит-полевошпатовых метасоматитах встречаются микровключения монацита и ксенотима. Монацит содержит $\mathrm{LREE}_{2} \mathrm{O}_{3}$ 52,05-69,54; $\mathrm{ThO}_{2}$ 0-10,45; ксенотим - $\mathrm{Y}_{2} \mathrm{O}_{3}$ 41,62-48,94; $\mathrm{HREE}_{2} \mathrm{O}_{3}$ 6,56-17,28; $\mathrm{ThO}_{2}$ 0-0,75; $\mathrm{UO}_{2}$ 0-0,90. Характерно присутствие циртолита: содержание $\mathrm{ZrO}_{2}$ составляет 54,81-68,42; каймы обогащены $\mathrm{HfO}_{2}$ до 2,$15 ; \mathrm{ThO}_{2}$ до 1,$58 ; \mathrm{UO}_{2}$ до 1,88 . В редких случаях биотитовые метасоматиты содержат редкоземельный ( $\mathrm{La}, \mathrm{Ce}, \mathrm{Nd})$ апатит- $(\mathrm{CaF})\left(\mathrm{LREE}_{2} \mathrm{O}_{3}\right.$ 0,22-32,99; $\mathrm{ThO}_{2}$ 1,21-2,96), ильменит $\left(\mathrm{WO}_{3} 3,62-5,56 ; \mathrm{Sc}_{2} \mathrm{O}_{3}\right.$ до 1,24), торит $\left(\mathrm{Y}_{2} \mathrm{O}_{3}\right.$ до 6,65). Минералом-концентратором редких элементов служит биотит: $\mathrm{Li}_{2} \mathrm{O}$ 0,04-0,43; $\mathrm{Rb}_{2} \mathrm{O}$ 0,06-0,32; $\mathrm{Cs}_{2} \mathrm{O}$ 0,01-0,06; $\mathrm{ZrO}_{2} 0,02-0,20 ; \mathrm{WO}_{3} 0$ 0,$09 ; \mathrm{SnO}_{2} 0-0,01 ; \mathrm{Y}_{2} \mathrm{O}_{3} 0-0,05$.

В грейзенах мусковит-квариевой стадии носителями редких элементов являются главные рудные минералы: касситерит $\left(\mathrm{WO}_{3} 0,02-0,56 ; \mathrm{Nb}_{2} \mathrm{O}_{5}\right.$ 0,02-0,18; $\left.\mathrm{Sc}_{2} \mathrm{O}_{3} 0,001-0,004\right)$, вольфрамит $\left(\mathrm{Nb}_{2} \mathrm{O}_{5}\right.$ 0,05-1,25; $\mathrm{Ta}_{2} \mathrm{O}_{5}$ 0-0,91; $\mathrm{Sc}_{2} \mathrm{O}_{3}$ 0,01-0,27; $\mathrm{La}_{2} \mathrm{O}_{3}$ 0-0,007). Относительно редко встречается молибденит с содержанием $\mathrm{Nb}_{2} \mathrm{O}_{5} 0-0,05 ; \mathrm{Ag}_{2} \mathrm{O} 0-0,04$. В мусковите установлено наличие примесей $\mathrm{Li}_{2} \mathrm{O} 0,01-0,56 ; \mathrm{WO}_{3} 0-0,02 ; \mathrm{SnO}_{2} 0-0,01$.

Минералы, содержащие редкие металлы, особенно разнообразны в рудных цвиттерах сидерофиллит-топазовой стадии (рисунок, в). В них выявлены редкометалльные минералы: фергусонит $\left(\mathrm{Nb}_{2} \mathrm{O}_{5}\right.$ 49,18-54,16; $\mathrm{Y}_{2} \mathrm{O}_{3}$ 22,15-32,50; $\mathrm{HREE}_{2} \mathrm{O}_{3}$ 9,27-34,41; $\mathrm{LREE}_{2} \mathrm{O}_{3}$ 0-2,71), эвксенит $\left(\mathrm{Nb}_{2} \mathrm{O}_{5} 52,99-62,81 ; \mathrm{Y}_{2} \mathrm{O}_{3}\right.$ 9,88-22,12; $\mathrm{WO}_{3}$ 9,52-13,72), плюмбопирохлор $\left(\mathrm{Nb}_{2} \mathrm{O}_{5}\right.$ 44,56-56,22; $\mathrm{Y}_{2} \mathrm{O}_{3}$ 0-13,98; $\mathrm{WO}_{3}$ 10,34-18,54), монацит (LREE $\mathrm{O}_{3} 49,28-66,86 ; \mathrm{ThO}_{2}$ 0,48-10,71; $\mathrm{UO}_{2}$ 0,37-2,14), ксенотим ( $\mathrm{Y}_{2} \mathrm{O}_{3}$ 35,75-51,45; $\mathrm{HREE}_{2} \mathrm{O}_{3}$ 14,34-25,67; LREE $\mathrm{O}_{3}$ 0-2,38; $\mathrm{ThO}_{2}$ 0-1,63; $\mathrm{UO}_{2}$ 0,58-3,73), циркон $\left(\mathrm{ZrO}_{2} 55,38-70,11 ; \mathrm{HfO}_{2}\right.$ 0,29-1,98; $\mathrm{ThO}_{2}$ 0-0,41; $\mathrm{UO}_{2}$ 0-1,48) [4]. В метасоматитах Верхнеурмийского массива и Правоурмийского месторождения описаны находки берилла.

Главные рудные минералы - вольфрамит и касситерит (рисунок, б), содержат W, Nb, Sc, In: вольфрамит - $\mathrm{WO}_{3} 66,41-77,77 ; \mathrm{Nb}_{2} \mathrm{O}_{5} 0-2,15 ; \mathrm{Sc}_{2} \mathrm{O}_{3} 0-1,41 ; \mathrm{Y}_{2} \mathrm{O}_{3} 0-0,07$; касситерит - $\mathrm{WO}_{3} 0-0,94$; $\mathrm{Nb}_{2} \mathrm{O}_{5}$ 0,01-0,13; $\mathrm{Sc}_{2} \mathrm{O}_{3}$ 0,001-0,012; $\mathrm{In}_{2} \mathrm{O}_{3}$ 0-0,001. Наиболее высокие концентрации редких элементов характерны для минералов западной части ВУРУ, расположенной в гранитах Верхнеурмийского массива $[4,8]$. Второстепенные рудные минералы также обогащены редкими элементами: шеелит - $\mathrm{WO}_{3} 69,66-87,53 ; \mathrm{MoO}_{3}$ 0,36-10,46; сфалерит - $\mathrm{CdO}$ 0-1,04. В отдельных случаях наблюдается обогащение редкометалльными примесями самородного висмута $\left(\mathrm{SeO}_{2}\right.$ до 1,50$)$; рутила $\left(\mathrm{Nb}_{2} \mathrm{O}_{5}\right.$ до 1,$30 ; \mathrm{WO}_{3}$ до 4,17), ильменита $\left(\mathrm{WO}_{3}\right.$ до 2,84$)$. Существенные объемы редких металлов заключены в жильных минералах цвиттеров: флюорите, сидерофиллите и мусковите [8]. Флюорит цвиттеров обогащен $\mathrm{Y}_{2} \mathrm{O}_{3}$ до 0,47 , содержит полный спектр тяжелых $($ до 0,14$)$ и легких (до 0,07) РЗЭ. Сидерофиллит содержит $\mathrm{Li}_{2} \mathrm{O}$ 0,05-1,53; $\mathrm{Rb}_{2} \mathrm{O}$ 0,12-0,60; $\mathrm{Cs}_{2} \mathrm{O}$ 0,01-0,15; $\mathrm{SnO}_{2}$ 0,01-0,62; $\mathrm{WO}_{3}$ 0,001-0,015; мусковит - $\mathrm{Li}_{2} \mathrm{O}$ 0,01-0,65; $\mathrm{Rb}_{2} \mathrm{O} 0,03-0,11 ; \mathrm{Cs}_{2} \mathrm{O} 0-0,01 ; \mathrm{SnO}_{2}$ $0-0,03 ; \mathrm{WO}_{3} 0,01-0,18$.

В турмалинитах квари-турмалиновой стадии собственно редкометалльные минералы встречаются редко. В виде включений в турмалине зафиксированы монацит $\left(\operatorname{LREE}_{2} \mathrm{O}_{3} 49,20-51,04\right.$; $\mathrm{ThO}_{2}$ 3, 17-3,95), циркон $\left(\mathrm{ZrO}_{2} 61,68-70,73 ; \mathrm{HfO}_{2}\right.$ 0,13-3,04; $\mathrm{ThO}_{2} 0,09-1,00 ; \mathrm{UO}_{2}$ 0,20-1,25), шеелит $\left(\mathrm{WO}_{3} 86,90\right)$. В составе сульфидных выделений описан рокезит $\left(\mathrm{In}_{2} \mathrm{O}_{3} 51,26-56,91\right.$; $\mathrm{CdO} 0,55-0,99$; $\mathrm{SnO}_{2}$ 0,75-1,16; $\mathrm{Ag}_{2} \mathrm{O}$ 0,34-0,99). В турмалиновых метасоматитах достаточно широк круг минералов, содержащих редкие металлы в виде примесей (рисунок, г). Среди них главные рудные минералы: касситерит ( $\left.\mathrm{WO}_{3} 0,07-0,18 ; \mathrm{Nb}_{2} \mathrm{O}_{5} 0-0,07 ; \mathrm{Sc}_{2} \mathrm{O}_{3} 0-0,01 ; \mathrm{In}_{2} \mathrm{O}_{3} 0-0,002\right)$, вольфрамит $\left(\mathrm{Nb}_{2} \mathrm{O}_{5}\right.$ $0,05-0,53 ; \mathrm{Sc}_{2} \mathrm{O}_{3}$ 0,01-0,03; $\mathrm{Y}_{2} \mathrm{O}_{3}$ 0,001-0,002), халькопирит $\left(\mathrm{SnO}_{2} 0,12-3,17 ; \mathrm{In}_{2} \mathrm{O}_{3} 0,01-0,94 ; \mathrm{Ag}_{2} \mathrm{O}\right.$ $0-0,53)$, станноидит $\left(\mathrm{SnO}_{2} 24,42-26,89 ; \mathrm{In}_{2} \mathrm{O}_{3} 0-0,67 ; \mathrm{CdO} 0-0,37 ; \mathrm{Ag}_{2} \mathrm{O} 0-0,74\right)$, борнит $\left(\mathrm{SnO}_{2}\right.$ $\left.0-3,75 ; \mathrm{In}_{2} \mathrm{O}_{3} 0-0,54 ; \mathrm{Ag}_{2} \mathrm{O} 0-0,33\right)$, самородный висмут $\left(\mathrm{SnO}_{2} 0-0,83 ; \mathrm{CdO} 0-0,63 ; \mathrm{Ag}_{2} \mathrm{O} 0-0,67\right)$, пирит $\left(\mathrm{WO}_{3} 1,69-4,35 ; \mathrm{SnO}_{2}\right.$ 0-0,17). Второстепенные минералы турмалинитов содержат примесь легких Р3Э ( $\mathrm{La}, \mathrm{Ce}, \mathrm{Nd})$, иттрия и иных редких металлов: эпидот $\left(\mathrm{LREE}_{2} \mathrm{O}_{3}\right.$ 15,84-21,21; $\mathrm{ThO}_{2}$ 0-0,99; $\mathrm{SnO}_{2}$ 0-0,69), флюорит $\left(\mathrm{Y}_{2} \mathrm{O}_{3}\right.$ 0,01-0,07; LREE $\mathrm{O}_{3}$ 0-0,06; $\mathrm{HREE}_{2} \mathrm{O}_{3} 0-0,02 ; \mathrm{Sc}_{2} \mathrm{O}_{3} 0-0,001$; $\left.\mathrm{SnO}_{2} 0,002-0,007\right)$.

Хлоритовые метасоматиты пострудной хлорит-серицитовой стадии не содержат редкометалльных минералов. Однако в характерной для них полиметаллической сульфидной минерализации наблюдаются примеси $\mathrm{In}, \mathrm{Cd}, \mathrm{Se}$ и других редких металлов: сфалерит - $\mathrm{CdO}$ 0,09-2,12; $\mathrm{In}_{2} \mathrm{O}_{3}$ 0,003-1,085; $\mathrm{SnO}_{2}$ 0-0,79; $\mathrm{Ag}_{2} \mathrm{O}$ 0-0,01; галенит - $\mathrm{SeO}_{2} 1,57-10,83 ; \mathrm{SnO}_{2} 0-0,07 ; \mathrm{In}_{2} \mathrm{O}_{3}$ 0-0,001; 
$\mathrm{Ag}_{2} \mathrm{O}$ 0,01-6,78. Флюорит хлорититов содержит $\mathrm{Y}_{2} \mathrm{O}_{3}$ 0-0,64; $\mathrm{HREE}_{2} \mathrm{O}_{3}$ 0-0,02; $\mathrm{LREE}_{2} \mathrm{O}_{3}$ 0-0,03; $\mathrm{SnO}_{2}$ 0-0,01; встречается эпидот с примесью $\mathrm{SnO}_{2}$ 0,44-6,40.

Обсуждение результатов. В статье показано наличие в составе оловоносных метасоматитов Верхнеурмийского рудного узла множества минералов редких металлов, которые имеют стратегическое значение для развития минерально-сырьевой базы России: $\mathrm{Nb}$, Ta, $\mathrm{W}, \mathrm{Y}, \mathrm{REE}$ (весь спектр от La до Lu), Be, Li, Zr, Hf, In, Sc, Se, Cd. В связи с этим возникают задачи исследования происхождения, эволюции редкометалльной минерализации и оценки ее практического значения. К важнейшим факторам формирования редкометалльной минерализации относятся магматический, метасоматический и кристаллохимический $[8,10-13,15,16]$.

Магматический и метасоматический факторы редкометалльной минерализации ВУРУ исследованы ранее. В изучаемом районе выделен правоурмийский редкометалльно-гранитовый комплекс, с которым связывается формирование крупных вольфрамово-оловорудных месторождений, несущих редкометалльную минерализацию $[1,2,5]$. Гидротермально-метасоматические условия формирования редкометалльных минералов дополнены в данной статье характеристикой минерального состава оловоносных метасоматитов. Разработана схема многостадийного развития пневматолитово-гидротермального процесса, определившего формирование вольфрамовооловорудного цвиттер-турмалинитового комплекса ВУРУ $[1,3,8,11,14]$.

Кристаллохимический фактор редкометалльной минерализации включает три самостоятельных условия: а) наличие в материнском расплаве редких элементов, кристаллохимически несовместимых с породообразующими элементами и накапливающихся в остаточных расплавах и флюидах; б) формирование редкими металлами в сочетании с родственными элементами (Ti, $\mathrm{Al}, \mathrm{Mn}, \mathrm{Fe}, \mathrm{Sn})$ политипных кристаллических структур, т.е. самостоятельных редкометалльных минералов [7]; в) изоморфное вхождение редких металлов в состав рудных и жильных минералов. Первому условию удовлетворяет рудно-магматическая система ВУРУ, обеспечившая масштабную пневматолито-гидротермальную переработку толщ, вмещающих Li-F-граниты, при участии флюидов, насыщенных F, Nb, Ta, Li, Zr, Be, Y, REE [1, 2, 4, 5, 8-11, 14]. Как показано в статье, в районе реализованы и два последних условия: среди минералов редких металлов отчетливо выделяются две категории - собственно редкометалльные минералы (фергусонит, эвксенит, плюмбопирохлор, алланит, циркон, монацит, ксенотим, рокезит) и минералы с примесями редких металлов - рудные (вольфрамит, касситерит, сульфиды $\mathrm{Cu}, \mathrm{Sn}, \mathrm{Fe}, \mathrm{Zn}, \mathrm{Pb}, \mathrm{Mo}$, шеелит, рутил, ильменит, самородный висмут) и жильные (флюорит, сидерофиллит, мусковит, эпидот). Применение локальных методов анализа позволило установить изоморфный характер примесей и отсутствие в изученных минералах микровключений редкометалльных фаз.

Пневматолитово-гидротермальные редкометалльные месторождения характеризуются, как правило, многостадийностью минералообразования и эволюцией редкометалльных ассоциаций. Приведенные в статье данные позволяют сделать вывод, что минералы редких металлов образуются в течение всей истории формирования цвиттер-турмалинитовой формации ВУРУ - от предрудной стадии биотитовых фельдшпатолитов до пострудной стадии хлорититов, включая рудную стадию цвиттеров. На первой, щелочной, стадии происходит накопление металлов цирконий-редкоземельной ассоциации, в грейзенах второй и третьей кислотных стадий концентрируются элементы иттрий-ниобий-вольфрамовой ассоциации, а для субщелочных метасоматитов четвертой и пятой стадий характерны примеси кадмий-индий-оловянной ассоциации: (LREE, Zr, $\mathrm{Hf}) \rightarrow(\mathrm{W}, \mathrm{Nb}, \mathrm{Ta}, \mathrm{Y}, \mathrm{HREE}, \mathrm{Sc}) \rightarrow(\mathrm{Sn}, \mathrm{In}, \mathrm{Cd}, \mathrm{Se})$. От ранних стадий к поздним наблюдается эволюция состава редких металлов от литофильных к халькофильным и снижение интенсивности редкометалльного минералообразования: собственные минералы редких металлов образуются преимущественно на ранних пневматолитовых стадиях минералогенеза.

Таким образом, установлена комплексная многостадийная редкометалльная минерализация ВУРУ, обязанная своим происхождением внедрению редкометалльных Li-F-гранитов. Выявлены магматический, метасоматический и кристаллохимический факторы образования минералов редких металлов, что может указывать на попутную редкометалльную рудоносность месторождений ВУРУ. К задачам на будущее относятся изучение соотношения и корреляции содержаний редких металлов и главных рудных компонентов $(\mathrm{Sn}, \mathrm{W}, \mathrm{Cu})$ в рудах, встречаемость редкометалльных минералов в метасоматитах различной стадийной и фациальной принадлежности, а также распределение редкометалльных минералов на территории района и конкретных рудопроявлений.

Записки Горного института. 2018. Т. 232. С. 335-340 • Геология 


\section{Выводы}

1. Установлено наличие в составе оловоносных метасоматитов Верхнеурмийского рудного узла множества минералов стратегических редких металлов: Nb, Ta, W, Y, REE (весь спектр от $\mathrm{La}$ до $\mathrm{Lu}), \mathrm{Be}, \mathrm{Li}, \mathrm{Zr}, \mathrm{Hf}, \mathrm{In}, \mathrm{Sc}, \mathrm{Se}, \mathrm{Cd}$. Выделены две формы концентрации редких металлов: редкометалльные минералы (фергусонит, эвксенит, плюмбопирохлор, алланит, циркон, монацит, ксенотим, рокезит) и изоморфные примеси в составе рудных минералов (вольфрамит, касситерит, сульфиды $\mathrm{Cu}, \mathrm{Sn}, \mathrm{Fe}, \mathrm{Zn}, \mathrm{Pb}, \mathrm{Mo}$, шеелит, рутил, ильменит, самородный висмут) и жильных минералов (флюорит, сидерофиллит, мусковит, эпидот).

2. Минералы, содержащие редкие металлы, образуются на всех стадиях формирования оловорудной цвиттер-турмалинитовой формации. От ранних стадий к поздним наблюдается снижение интенсивности редкометалльного минералообразования и эволюция состава редких металлов от литофильных к халькофильным: (LREE, Zr, Hf) $\rightarrow(\mathrm{W}, \mathrm{Nb}, \mathrm{Ta}, \mathrm{Y}, \mathrm{HREE}, \mathrm{Sc}) \rightarrow(\mathrm{Sn}, \mathrm{In}, \mathrm{Cd}, \mathrm{Se})$.

3. Выявлены магматический, метасоматический и кристаллохимический факторы образования минералов-концентраторов редких металлов, что может указывать на попутную редкометалльную рудоносность месторождений Верхнеурмийского рудного узла.

Благодарность. Исследования выполнены в рамках базовой части государственного задания Минобрнауки России в сфере научной деятельности № 5.9248.2017/6.7 на 2017-2019 годы.

\section{ЛИТЕРАТУРА}

1. Алексеев В.И. Дальневосточный пояс литий-фтористых гранитов, онгонитов и оловорудных цвиттеров // Записки Горного института. 2015. Т. 212. С. 14-20.

2. Алексеев В.И. Литий-фтористые граниты Дальнего Востока. СПб: Национальный минерально-сырьевой университет «Горный», 2014. 244 c.

3. Алексеев В.И. Метасоматическая зональность рудных полей Баджальского района (Приамурье) // Записки Всесоюзного минералогического общества. 1989. Вып. 5. С. 27-37.

4. Алексеев В.И. Ниобиевые минералы - индикаторы генетической связи оловорудных цвиттеров и литий-фтористых гранитов Верхнеурмийского массива (Приамурье) / В.И.Алексеев, К.Г.Суханова, Ю.Б.Марин // Записки Российского минералогического общества. 2018. № 1. С. 85-100.

5. Алексеев В.И. Эволюция минеральных форм накопления редких элементов в рудоносных гранитах и метасоматитах Верхнеурмийского рудного узла (Приамурье) / В.И.Алексеев, К.Г.Суханова, И.М.Гембицкая // Записки Горного института. 2017. T. 224. C. 149-155. DOI: 10.18454/PMI.2017.2.149

6. Быховский Л.3. Об определении понятия «редкие элементы» («редкие металлы»): исторический и терминологический аспекты / Л.З.Быховский, Л.П.Тигунов, А.В.Темнов // Минеральные ресурсы России. Экономика и управление. 2015. № 3. C. 32-38.

7. Волошин A.B. Тантало-ниобаты. Систематика, кристаллохимия и эволюция минералообразования в гранитных пегматитах. СПб: Наука, 1993. 298 с

8. Гавриленко В.B. Геохимия, генезис и типоморфизм минералов месторождений олова и вольфрама / В.В.Гавриленко, Е.Г.Панова. СПб: Невский курьер, 2001. 260 с.

9. Геодинамика, магматизм и металлогения Востока России: В 2 кн. / Под ред. А.И.Ханчука. Владивосток: Дальнаука, 2006. $981 \mathrm{c}$.

10. Гоневчук В.Г. Оловоносные магматические системы Дальнего Востока: магматизм и рудогенез. Владивосток: Дальнаука, 2002. 297 с.

11. Марин Ю.Б. Минералого-геохимические критерии локального прогнозирования редкометальных месторождений / Ю.Б.Марин, Г.Т.Скублов, Ю.Л.Гульбин // Минералогическое картирование и индикаторы оруденения. Л.: Наука, 1990. C. 67-94.

12. Минеральные ресурсы высокотехнологичных металлов в России: состояние и перспективы развития / Н.С.Бортников, А.В.Волков, А.Л.Галямов, И.В.Викентьев, В.В.Аристов, А.В.Лаломов, К.Ю.Мурашов // Геология рудных месторождений. 2016. Т. 58. № 2. С. 97-119.

13. Плющев Е.В. Металлогения гидротермально-метасоматических образований / Е.В.Плющев, В.В.Шатов, С.В.Кашин. СПб: Изд-во ВСЕГЕИ, 2012. 560 с. (ТрудЫ ВСЕГЕИ. Новая серия. Т. 354).

14. Семеняк Б.И. О «цвиттерах» Верхнеурмийского рудного узла // Рудные месторождения Дальнего Востока. Владивосток: ДВНЦ АН СССР, 1983. С. 20-25.

15.Так что же такое «редкометальный гранит»? / С.М.Бескин, Ю.Б.Марин, В.В.Матиас, С.П.Гаврилова // Записки Всесоюзного минералогического общества. 1999. Вып. 6. С. 28-40.

16. Rare Earth and Critical Elements in Ore Deposits / Ed. by Ph.L.Verplanck, M.W.Hitzman; Society of Economic Geologists, Inc. Broomfield, CO, USA. 365 p. (Reviews in Economic Geology. 2016. Vol. 18).

Автор В.И.Алексеев, д-р геол.-минерал. наук, профессор, Alekseev_VI@pers.spmi.ru (Санкт-Петербургский горный университет, Санкт-Петербург, Россия).

Статья поступила в редакиию 17.08.2017.

Статья принята к публикации 19.02.2018. 